\title{
Originals
}

\section{Bone Loss in Diabetes: Effects of Metabolic State}

\author{
P. McNair ${ }^{1}$, S. Madsbad ${ }^{2}$, C. Christiansen ${ }^{3}$, M. S. Christensen ${ }^{1}$, O. K. Faber ${ }^{2}$, C. Binder ${ }^{2}$, and I. Transbøl ${ }^{4}$ \\ ${ }^{1}$ Department of Clinical Chemistry, Glostrup Hospital, Glostrup, ${ }^{2}$ Hvidøre Hospital, Klampenborg, \\ ${ }^{3}$ Department of Clinical Chemistry, and ${ }^{4}$ Division of Endocrinology, Department of Internal Medicine, Hvidovre Hospital, \\ University Hospital of Copenhagen, Hvidovre, Denmark
}

Summary. The significance of different risk factors for the development of bone loss in diabetes mellitus was evaluated in a cross sectional study of 215 insulin treated diabetic outpatients. Bone mineral content in the forearms was measured by photon absorptiometry and the metabolic status was evaluated by three indices: residual B-cell function, insulin dosage and fasting blood glucose. The mean bone mineral content was reduced to $90.2 \%$ of sex- and agematched normal mean values $(\mathrm{P}<0.001)$. Stratification of the patients showed that bone mineral content was $99.3 \%$ of that found in sex- and age matched normal subjects in the group with residual B-cell function, low insulin dosage and low fasting blood glucose; it was only $79.3 \%$ of normal in the group with no detectable insulin secretion, high insulin dosage and more severe hyperglycaemia. Thus, residual insulin secretion and the quality of metabolic control are major factors in determining bone mineral content in insulin treated diabetic patients.

Key words: Bone mineral content, diabetes mellitus, diabetic control, insulin secretion, insulin dosage, fasting blood glucose.

Recent evidence suggests that bone loss should be included among the complications of insulin treated diabetes mellitus [1-4]. The reduction in bone mineral content (BMC) becomes detectable 2-3 years after onset of clinical diabetes, attaining a stable level of about $90 \%$ of normal BMC after about 5 years of diabetes [5]. Low BMC has been related to early diabetes onset (before the age of 20-25 years) [5], to a high daily tobacco consumption [6] and to the fol- lowing indices of diabetes control: low or absent insulin secretion, high daily insulin dosage and hyperglycaemia [7]. The present study was designed to evaluate the additive effects of these interrelated indices of diabetic control on diabetic bone loss.

\section{Patients}

The investigation was carried out as a cross-sectional study of 215 insulin treated diabetics with varying length of clinical diabetes (between $0-29$ years, mean duration 10 years). All patients gave informed consent to the study. The patients' ages were $7-70$ years and all had a normal serum creatinine level $(<115 \mu \mathrm{mol} / 1)$. None of the patients had other diseases or received drugs known to interfere with mineral metabolism [5]. The patients were invited to participate in a study of calcium metabolism outside the diabetes clinic (see discussion). Blood samples were drawn in the morning after an overnight fast before administration of insulin.

\section{Methods \\ Bone mineral content (BMC) was measured in both forearms by photon absorptiometric scanning at 6 positions on the distal part of each forearm, as described in detail previously $[5,8]$. In each patient the mean value of these scans was calculated as $\%$ mean BMC value of sex- and age matched controls (2 year age groups for children and adolescents and 10 year age groups for adults). The influence of sex and age was thus minimized and this value for bone mineral content was suitable for evaluation. The method has a high precision (coefficient of variation: 1.2\%) [9], but the interindividual variation is considerable $(\mathrm{SD}=16 \%$ ) in normal subjects [10].}

Endogenous insulin secretion was estimated by measuring the serum concentration of immunoreactive $C$-peptide $6 \mathrm{~min}$ after IV injection of $1 \mathrm{mg}$ glucagon. Patients with a serum C-peptide level exceeding the upper limit of C-peptide levels measured in 10 pancreatectomized patients $(0.05 \mathrm{nmol} / 1)$ were considered to have residual insulin secretion and were designated secretors [11].

The insulin dose was calculated for each patient as insulin IU/ $\mathrm{kg}$ body weight/day at the time of the investigation. 
Table 1. Bone mineral content (BMC) and duration of disease in insulin treated diabetic patients stratified successively according to increasing risk of bone loss (left part): Early age at onset of diabetes (a) + undetectable B-cell function ("non-secretor") (b) + high insulin dose $(c)+$ high fasting blood glucose concentration (d). The right part of table gives results for the patients excluded at each selection

\begin{tabular}{|c|c|c|c|c|c|c|c|}
\hline \multirow{3}{*}{$\begin{array}{l}\text { Selection } \\
\text { according to } \\
\text { high risk }\end{array}$} & \multicolumn{4}{|c|}{ Patients included } & \multicolumn{3}{|c|}{ Patients excluded } \\
\hline & & & BMC ( $\%$ of normal) & Mean duration & & & $\mathrm{BMC}(\%$ of normal) \\
\hline & Group & $\mathrm{n}$ & Mean \pm SEM & years & Group & $\mathbf{n}$ & Mean \pm SEM \\
\hline All patients & & 215 & $90.2 \pm 1.0$ & 10.0 & & - & - \\
\hline \multicolumn{8}{|l|}{ Age at onset } \\
\hline before 21 years & a & 86 & $86.1 \pm 1.3$ & 8.5 & $a_{e}$ & 129 & $92.9 \pm 1.3$ \\
\hline Non-secretor & $\mathrm{b}$ & 70 & $84.8 \pm 1.2$ & 10.0 & $b_{e}$ & 16 & $91.8 \pm 4.1$ \\
\hline \multicolumn{8}{|l|}{ Insulin dose } \\
\hline$>0.7 \mathrm{IU} / \mathrm{kg} / \mathrm{day}$ & $\mathrm{c}$ & 35 & $82.3 \pm 1.5$ & 8.9 & $\mathrm{c}_{\mathrm{e}}$ & 35 & $87.2 \pm 1.9$ \\
\hline \multicolumn{8}{|l|}{ Fasting blood glucose } \\
\hline$>14.8 \mathrm{mmol} / \mathrm{l}$ & d & 18 & $79.3 \pm 1.9$ & 8.9 & $\mathrm{~d}_{\mathrm{e}}$ & 17 & $85.4 \pm 2.3$ \\
\hline
\end{tabular}

Analyses of variance (concerning groups $d+d_{e}+c_{e}+b_{e}+a_{e}$ ): $P<0.001$

Table 2. Bone mineral content (BMC) and duration of disease in insulin treated diabetic patients stratified successively according to decreasing risk of bone loss (left part): Age at onset of diabetes after 25 years (A) + residual B-cell function ("secretor") (B) + low insulin dose (C) + low fasting blood glucose concentration (D). The right part of the table gives results for the patients excluded at each selection

\begin{tabular}{|c|c|c|c|c|c|c|c|}
\hline \multirow{3}{*}{$\begin{array}{l}\text { Selection } \\
\text { according to } \\
\text { low risk }\end{array}$} & \multicolumn{4}{|c|}{ Patients included } & \multicolumn{3}{|c|}{ Patients excluded } \\
\hline & & & $\mathrm{BMC}(\%$ of normal) & Mean duration & & & BMC ( $\%$ of normal) \\
\hline & Group & $\mathrm{n}$ & Mean $\pm \mathrm{SEM}$ & years & Group & $\mathrm{n}$ & Mean $\pm \mathrm{SEM}$ \\
\hline All patients & & 215 & $90.2 \pm 1.0$ & 10.0 & & - & - \\
\hline \multicolumn{8}{|l|}{ Age at onset } \\
\hline after 25 years & A & 129 & $92.9 \pm 1.3$ & 11.0 & $A_{e}$ & 86 & $86.1 \pm 1.3$ \\
\hline Secretors & B & 54 & $93.9 \pm 1.8$ & 6.8 & $\mathrm{~B}_{\mathrm{e}}$ & 75 & $92.3 \pm 1.8$ \\
\hline \multicolumn{8}{|l|}{ Insulin dose } \\
\hline$<0.37 \mathrm{IU} / \mathrm{kg} /$ day & $\mathrm{C}$ & 28 & $97.3 \pm 2.8$ & 6.0 & $\mathrm{C}_{\mathrm{e}}$ & 26 & $90.2 \pm 2.2$ \\
\hline \multicolumn{8}{|l|}{ Fasting blood glucose } \\
\hline$<11.1 \mathrm{mmol} / \mathrm{l}$ & $\mathrm{D}$ & 14 & $99.3 \pm 3.4$ & 7.9 & $\mathrm{D}_{\mathrm{e}}$ & 14 & $95.2 \pm 4.4$ \\
\hline
\end{tabular}

Analyses of variance (concerning groups $\mathrm{D}+\mathrm{D}_{\mathrm{e}}+\mathrm{C}_{\mathrm{e}}+\mathrm{B}_{\mathrm{e}}+\mathrm{A}_{\mathrm{e}}$ ): $\mathrm{P}<0.005$

Glucose was measured in blood by an enzymatic analysis [12] and serum creatinine by the Jaffé reaction modified for the SMA 6/60 autoanalyzer.

Stratification of the patients. We have previously found that low $B M C$ is correlated with early onset of diabetes [5] and to the following indices of diabetes: low serum C-peptide concentration, high insulin dosage, high fasting blood glucose and glycosuria [7].

In order to elucidate this multifactorial relationship the patients were stratified according to high/low risk of $\mathrm{BMC}$ reduction (Tables 1 and 2, left part). Table 1 gives the results after stratification for high risk of bone loss: 86 of 215 patients had an onset of diabetes before the age of 21 years and 70 of the 86 were non-secretors. Thirty-five of the 70 patients were treated with more than $0.7 \mathrm{IU} / \mathrm{kg} /$ day, which was the median daily insulin dose in the 70 non-secretors. Finally the 18 patients with the highest blood glucose level were selected from the group of 35 patients. Table 2 gives the results after stratification for low risk of bone loss: 129 patients had onset of diabetes after 25 years of age, 54 of these were secretors, and in 28 diabetics the daily insulin dose was below $0.37 \mathrm{IU} / \mathrm{kg} /$ day (median value of the 54 patients). Of these,
14 patients had a blood glucose value below the median for the 28 $(11.1 \mathrm{mmol} / \mathrm{l})$. The right part of both tables gives the results for the patients excluded at each selection.

Statistical evaluation. Analysis of variance and Spearman Rank correlation analysis were used for statistical evaluation of results.

\section{Results}

The mean BMC of all diabetics was reduced to $90.2 \%$ of the mean normal value $(\mathrm{P}<0.001)$. The influence of the diabetic "risk factors" appears from Tables 1 and 2. Table 1 demonstrates the gradual decrease in BMC with successive selection of the patients with the highest risk of bone loss. A stepwise reduction in $\mathrm{BMC}$ is seen to a minimum mean value of $79.3 \%$ normal in the patients with the poorest metabolic control. 
Table 2 shows the opposite, i.e. the gradual increase in mean BMC with successive selection of the patients with the lowest risk of bone loss. In this way mean BMC is seen to rise stepwise to a maximum of $99.3 \%$ of normal in the patients with the best metabolic status.

If glycosuria was used for the last stratification instead of the fasting blood glucose level, the results were similar.

Stratification according to risk factors subdivided the patients into groups with strictly comparable duration of diabetes. In the entire series BMC was inversely correlated with the fasting blood glucose level $(\mathrm{R}=-0.17, \mathrm{P}<0.02)$ and daily insulin dose $(\mathrm{R}=-0.22, \mathrm{P}<0.002)$, and positively with the $\mathrm{C}-$ peptide level $(\mathrm{R}=0.19, \mathrm{P}<0.005)$.

\section{Discussion}

None of the indices of metabolic control used in the present study estimates accurately the overall metabolic state of the patient. The combination of these indices may, however, provide a sufficient estimate of the severity of the disturbances in glucose homeostasis. In fact, a bone loss of $20.7 \%$ was found in the patients selected to have the poorest metabolic state on the day of study, whereas no bone loss was found in patients with the mildest disturbances.

It may seem surprising that the dependency of bone mineral content on metabolic status was so readily documented in view of the controversies about the role of metabolic control for the vascular complications, still present after 50 years of insulin treatment $[13,14]$. The large number of patients studied as well as the high precision and accuracy of the measurement of BMC are both important factors. Furthermore, the patients were studied outside the diabetic clinic, and had 1.8 times higher $24 \mathrm{~h}$-glycosuria compared with the most recent visits at the diabetes clinic [15]. The higher glycosuria may indeed give a better estimate of the "every day" metabolic state. Our indices of metabolic status are certainly interrelated, but characterize the state of control in different ways [16-19]. Residual B-cell function is known to contribute to good metabolic control, most easily shown by the smaller insulin requirement of patients with preserved insulin secretion [16]. The dosage of insulin reflects a number of variables, affecting blood and urine glucose levels at the preceding visits to the clinic. Residual B-cell function and insulin dosage may both be relatively good indices of long-term metabolic control.

Our data provide an explanation for the reported normal bone mineral content in well-controlled diabetics treated exclusively with diet and/or oral antidiabetics [20]. Levin et al. [1] found a minor reduction of BMC in their diabetics treated with diet and/or sulphonylureas, but contrary to the patients studied by De Leeuw and Abs [20] they had not selected their patients to be especially well-controlled.

The increased frequency of bone fractures previously reported in diabetics $[21,22]$ is comprehensible in view of the $20 \%$ loss of bone minerals found in the poorly controlled patients.

Acknowledgements. This work was supported by grants from the Danish Hospital Foundation for Medical Research, Region of Copenhagen, Faroe Islands, and Greenland; the Danish Diabetic Association; the Danish Medical Research Council; and Dr. Erik Garde and Elisabeth Garde's Fund.

\section{References}

1. Levin, M. E., Boisseau, V. C., Avioli, L. V.: Effects of diabetes mellitus on bone mass in juvenile and adult-onset diabetes. $\mathrm{N}$. Engl. J. Med. 294, 241-245 (1976)

2. Ringe, J.-D., Kuhlencordt, F., Kühnau, Jr. J.: Mineralgehalt des Skeletts bei Langzeitdiabetikern. Densitometrischer Beitrag zur "Osteopathia diabetica". Dtsch. Med. Wochenschr. 101, 280-282 (1976)

3. McNair, P., Madsbad, S., Christiansen, C., Transbøl, I., Faber, O. K., Binder, C.: Bone mineral loss in diabetes mellitus. Acta Endocrinol. [Suppl. 209] (Kbh.) 85, 45 (1977)

4. Rosenbloom, A. L., Lezotte, D. C., Weber, F.T., Gudat, J., Heller, D. R., Weber, M. L., Klein, S., Kennedy, B. B.: Diminution of bone mass in childhood diabetes. Diabetes 26, 1052-1055 (1977)

5. McNair, P., Madsbad, S., Christiansen, C., Faber, O.K. Transbøl, I., Binder, C.: Osteopenia in insulin treated diabetes mellitus: Its relation to age at onset, sex and duration of disease. Diabetologia 15, 87-90 (1978)

6. McNair, P., Christensen, M. S., Madsbad, S., Christiansen, C., Binder, C., Transbøl, I.: Bone loss in patients with diabetes mellitus: Effects of smoking. Mineral and electrolyte metabolism (In press)

7. McNair, P., Madsbad, S., Christensen, M. S., Christiansen, C., Faber, O. K., Binder, C., Transbøl, I.: Bone mineral loss in insulin-treated diabetes mellitus: Studies on pathogenesis. Acta Endocrinol. (Kbh.) 90, 463-472 (1979)

8. Christiansen, C., Rødbro, P., Jensen, H.: Bone mineral content in the forearm measured by photon absorptiometry. Principles and reliability. Scand. J. Clin. Lab. Invest. 35, 323-330 (1975)

9. Christiansen, C., Rødbro, P.: Long-term reproducibility of bone mineral content measurements. Scand. J. Clin. Lab. Invest. 37, 321-323 (1977)

10. Christiansen, C., Rødbro, P.: Bone mineral content and estimated total body calcium in normal adults. Scand. J. Clin. Lab. Invest. 35, 433-439 (1975)

11. Hendriksen, C., Faber, O. K., Drejer, J., Binder, C.: Prevalence of residual B-cell function in insulin-treated diabetics evaluated by the plasma $\mathrm{C}$-peptide response to intravenous glucagon. Diabetologia 13, 615-619 (1977)

12. Holm, H., Pianezzi, A., Scholer, A.: Mikrometode zur Bestimmung der Glucosekonzentration aus 20 ul Probe auf dem Auto-Analyzer. Z. Klin. Chem. Klin. Biochem. 13, 541-543 (1975) 
13. Cahill, Jr. G. F., Etzwiler, D. D., Freinkel, N.: "Control" and diabetes. N. Engl. J. Med. 294, 1004-1005 (1976)

14. Siperstein, M. D., Foster, D. W., Knowles, Jr., H. C., Levine, R., Madison, L. L., Roth, J.: Control of blood glucose and diabetic vascular disease. N. Engl. J. Med. 296, 1060-1063 (1977)

15. Madsbad, S., McNair, P., Faber, O. K., Binder, C., Christiansen, C., Transbøl, I.: Beta-cell function and metabolic control in insulin treated diabetics. Acta Endocrinol. (Kbh.) (In press)

16. Faber, O. K., Binder, C.: B-cell function and blood glucose control in insulin dependent diabetics within the first month of insulin treatment. Diabetologia 13, 263-268 (1977)

17. Enk, B.: Insulin secretion in insulin-requiring diabetics before and during insulin treatment. Acta Endocrinol. (Kbh.) 85, 559-570 (1977)

18. Yue, D. K., Baxter, R. C., Turtle, J. R.: C-peptide secretion and insulin antibodies as determinants of stability in diabetes mellitus. Metabolism 27, 35-44 (1978)

19. Shima, K., Tanaka, R., Morishita, S., Tarvi, S., Kumahara, Y., Nishikawa, M.: Studies on the etiology of "brittle diabetes".
Relationship between diabetic instability and insulinogenic reserve. Diabetes 26, 717-725 (1977)

20. De Leeuw, I., Abs., R.: Bone mass and bone density in maturity type diabetics measured by the ${ }^{125} \mathrm{I}$ photon absorption technique. Diabetes 26, 1130-1135 (1977)

21. Alfram, P. A.: An epidemiologic study of cervical and trochanteric fractures of the femur in an urban population. Acta Orthop. Scand. 65 [Suppl.] (1964)

22. Menczel, J., Makin, M., Robin, G., Joge, I., Naor, E.: Prevalence of diabetes mellitus in Jerusalem. Its association with presenile osteoporosis. Isr. J. Med. Sci. 8, 918-919 (1972)

Received: September 19, 1978,

and in revised form: May 22, 1979

Dr. Peter McNair

Department of Clinical Chemistry

Glostrup Hospital

DK-2600 Glostrup

Denmark 